\title{
Who owns and is responsible for the elephant in the room? Management plans for free-roaming elephant in South Africa
}

\begin{tabular}{|c|c|}
\hline \multicolumn{2}{|c|}{$\begin{array}{l}\text { Authors: } \\
\text { Andrew C. Blackmore } \mathrm{e}^{1,2} \bullet \\
\text { Arie Trouwborst }{ }^{3} \bullet\end{array}$} \\
\hline \multicolumn{2}{|c|}{ 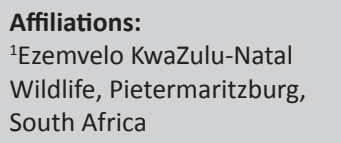 } \\
\hline \multicolumn{2}{|c|}{$\begin{array}{l}{ }^{2} \text { School of Law, University of } \\
\text { KwaZulu-Natal, South Africa }\end{array}$} \\
\hline \multicolumn{2}{|c|}{$\begin{array}{l}{ }^{3} \text { Department of European } \\
\text { and International Public Law, } \\
\text { Tilburg University, the } \\
\text { Netherlands }\end{array}$} \\
\hline \multicolumn{2}{|c|}{$\begin{array}{l}\text { Corresponding author: } \\
\text { Andrew Blackmore, } \\
\text { andy.blackmore@ } \\
\text { kznwildlife.com }\end{array}$} \\
\hline \multicolumn{2}{|c|}{$\begin{array}{l}\text { Received: } 16 \text { Dec. } 2017 \\
\text { Accepted: } 24 \text { Jan. } 2018 \\
\text { Published: } 07 \text { June } 2018\end{array}$} \\
\hline \multicolumn{2}{|c|}{$\begin{array}{l}\text { How to cite this article: } \\
\text { Blackmore, A.C., \& } \\
\text { Trouwborst, A., 2018,'Who } \\
\text { owns and is responsible for } \\
\text { the elephant in the room? } \\
\text { Management plans for } \\
\text { free-roaming elephant in } \\
\text { South Africa', Bothalia 48(2), } \\
\text { a2271. https://doi.org/ } \\
\text { 10.4102/abc.v48i2.2271 }\end{array}$} \\
\hline \multicolumn{2}{|c|}{$\begin{array}{l}\text { Copyright: } \\
\text { @ 2018. The Authors. } \\
\text { Licensee: AOSIS. This work } \\
\text { is licensed under the } \\
\text { Creative Commons } \\
\text { Attribution License. }\end{array}$} \\
\hline \multicolumn{2}{|l|}{ Read online: } \\
\hline 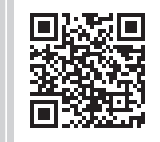 & $\begin{array}{l}\text { Scan this QR } \\
\text { code with your } \\
\text { smart phone or } \\
\text { mobile device } \\
\text { to read online. }\end{array}$ \\
\hline
\end{tabular}

In 2008, South Africa adopted its 'National Norms and Standards for the Management of Elephants in South Africa'. Concern has subsequently been raised as to whether these norms and standards apply to free-ranging elephant on land, which had not been enclosed with a fence with the express purpose of containing these animals and other game on the property. The application of these norms and standards pivots on whether the owner(s) of the property have taken possession of these animals in accordance with common law applicable to game, or have given effect to the provisions of the Game Theft Act. To address this concern, this article briefly explores the evolution of South African regulatory jurisprudence applicable to game, including elephant, and analyses the norms and standards in relation to international and national legislation and common law applying to elephants. The norms and standards are not applicable to unowned, free-roaming elephant. These norms and standards, therefore, do not fulfil their primary objective of uniform management of elephant across South Africa. This limitation of the norms and standards, therefore, needs to be considered when they are revised.

\section{The conundrum}

The National Norms and Standards for the Management of Elephants in South Africa implemented in terms of Section 9 of the National Environmental Management Biodiversity Act 10 of 2004 (NEMBA) require landowners or the management authority (as the case may be) with wild elephant on their properties to compile and have adopted an elephant management plan by the relevant political head (DEAT 2008). While norms and standards are generally not legally binding in that they provide authoritative guidance to officials when implementing the legislation (Hopkinson, Van Staden \& Ridl 2008), the adoption of these norms and standards in terms of NEMBA renders them enforceable. The norms and standards apply to land that has been declared as a protected area, is a registered game farm or which is private or communal land. Furthermore, such land is required to be appropriately fenced in order to contain the elephant. The norms and standards are, however, not explicit as to who is responsible for free-roaming elephant that has not been restrained by fences or which has crossed over from countries neighbouring South Africa.

The purpose of this article is to gain an understanding of the provisions in South African and international law that would point to who is responsible - if anyone at all - for developing and having adopted by the relevant authority a management plan for a single elephant or groups or populations of elephant that are considered free-roaming and are not enclosed within a fenced estate. To achieve this, the article first introduces the history and international context of elephant management plans. Subsequently, it delves into the questions of ownership of, and responsibility for, elephant - and the specific issue of elephant management plans.

\section{A brief history and international context of elephant management plans}

The use, and hence ownership, of wildlife has been a hot topic in South Africa at least since the early rule of Van Riebeek in the Cape Colony where certain sectors of society were precluded from hunting (Couzens \& Blackmore 2010; Rabie 1976). For the next 200 years, various governors attempted to curtail the consumptive use of wildlife in that they believed that unregulated or indiscriminate hunting had led to the demise of this resource in the Colony (Couzens \& Blackmore 2010). In the late 1800s, the Cape Colony introduced the Better Preservation of Game Act 36 of 1886 , which restricted the right to, inter alia, 'kill, catch, capture, pursue, hunt, or shoot game' by the 
landowner, unless the person wishing to undertake such an activity possessed a licence (Mackenzie 1988). This right could be established by the landowner issuing a warning either in person, or by letter or a notice in the Gazette or local newspaper, with the intention to preserve the game on the land in question (Tennant \& Jackson 1895). In many respects, notwithstanding an encroachment on the res nullius status of game (Couzens \& Blackmore 2010), this provision was the earliest legal foundation for the establishment of a 'game farm' or 'private protected area', in that this Act granted the landowner an unfettered right to manage and protect wildlife on his or her property.

Similarly, the colonial powers in Africa expressed concern over the significant decrease in wildlife throughout the continent. This concern was rooted in the Convention for the Preservation of Wild Animals, Birds, and Fish in Africa (1900 London Convention). Although this Convention never entered into force, it was significant in that it not only brought into the international arena the possible consequences of unregulated, commutative use of wildlife and the potential extinction of species such as elephant, but also introduced the need to establish extensive systems of 'reserves' in which indigenous wildlife could persist in an undisturbed or wild state (Article II). Such a state was deemed to be achieved only when the land set aside for this purpose had 'all the qualifications necessary as regards food, water, and, if possible, salt, for preserving birds or other wild animals, and for affording them necessary quiet during the breeding time' (Article II). It was the intent of the Convention to facilitate domestic legislation that rendered it unlawful to generally 'hunt, capture, or kill any bird or other wild animal except those which shall be specially exempted from protection by the local authorities' (Article II). This provision naturally provides for the requirement that the reserve be actively monitored and managed in order for the reserve authority to be in a position to grant such exemptions and continue to fulfil the intent of the Convention. The drafting of this Convention was deemed to be profound, in that it represented the earliest record requiring the management, protection and conservation of, inter alia, elephant. These provisions of the 1900 London Convention were enhanced by subsequent multilateral environmental agreements culminating in the 1968 African Convention on the Conservation of Nature and Natural Resources (Algiers Convention). One of the hallmarks of this latter Convention is the explicit requirement of management plans 'based on scientific principles' - for, inter alia, the management of wildlife inside 'designated areas' in accordance with the objectives of such areas, and also to 'manage exploitable wildlife populations outside such areas [...], compatible with and complementary to other land uses' (Article VII). It can be assumed that 'designated areas', although not defined in the Convention, would reasonably include conservation areas such as formal protected areas. Parties are furthermore required to ensure that the elephant is protected both within and outside protected areas - entailing a prohibition on hunting, killing and capture, except when specially authorised by the competent authorities (Article VIII). South Africa, however, is neither party nor signatory to the Algiers Convention.
The Algiers Convention has recently been replaced by the 2003 revised African Convention on the Conservation of Nature and Natural Resources (Maputo Convention) although the Algiers Convention remains in force for parties that are not (yet) bound by the Maputo Convention.

Whereas the Maputo Convention had not entered into force when the elephant norms and standards were adopted, South Africa was under a general obligation to 'refrain from acts which would defeat the object and purpose' of the Convention since it signed the Convention in 2012 (1969 Vienna Convention on the Law of Treaties, Article 18). This, and more so since the Convention was brought into force on 07 March 2017, together with the active role played by South Africa in the development of the Maputo Convention, put this multilateral agreement at an equivalent level to domestic policy. Furthermore, South Africa played an active role in developing the Maputo Convention and as noted elsewhere (see Blackmore 2017), the Convention influenced the formulation of the NEMBA and the regulations thereto. Since its entry into force on 23 July 2016, the Convention requires South Africa to manage animal populations within the country's array of conservation areas in accordance with the objectives of such areas. In addition, the Convention requires, inter alia, that contracting parties provide appropriate protection to currently or potentially threatened species, and the same for species that are migratory or congregatory (Article XI and X), while 'taking into particular account the need to develop or maintain throughout the African continent concerted protection measures for such species' (Article $X(2)$ ). It stands to reason that these provisions may be met by way of, inter alia, a species-specific management plan, such as that provided in Section 9 of NEMBA. This is the legal foundation for affected landowners to develop and implement an elephant management plan, as provided for in the National Norms and Standards for the Management of Elephants in South Africa (DEAT 2008). Moreover, 'whenever a natural resource [a term including "fauna"] is transboundary', the Maputo Convention requires the parties involved to 'undertake to cooperate in the conservation, development and management of such resource [...] and if the need arises, set up interstate commissions for their conservation and sustainable use' (Article XXII(2)(e)). Significantly, one of the stated objectives of these elephant norms and standards is to ensure that elephant management in South Africa is regulated in a way that conforms to the country's 'international obligations in terms of international agreements on biodiversity management binding on the Republic' (Section 2).

The non-binding but authoritative World Charter for Nature, adopted by the UN General Assembly in 1982, contains a general requirement that '[a]ll planning shall include, among its essential elements, the formulation of strategies for the conservation of nature'. The equally general provisions in the 1992 Convention on Biological Diversity include an obligation for states to develop 'national strategies, plans or programmes for the conservation and sustainable use of biological 
diversity or adapt for this purpose existing strategies, plans or programmes' (Article 6).

Finally, while not requiring specific domestic wildlife management plans, the Southern African Development Community's (SADC) Protocol on Wildlife Conservation and Law Enforcement (SADC 1999) imposes an obligation on each of its contracting parties, including South Africa, to 'ensure the conservation and sustainable use of wildlife resources under its jurisdiction' and to take 'such policy, administrative and legal measures as appropriate' to achieve this (Article 3). Furthermore, it sets in place the foundation for broad wildlife management and enforcement cooperation across SADC state boundaries. Given that elephant populations abutting the country's borders have or may have home ranges that are transboundary in nature, management of these populations, and hence the associated management plans, would need to be aligned between the affected countries. The significance of the SADC Protocol to this issue is briefly revisited below.

\section{Ownership of and responsibility for elephant in a nutshell}

The conundrum is who owns the free-ranging elephant? South Africa, as did many other countries, founded its legal system on Roman or Roman-Dutch law (Muir 2016). In these legal systems, game (including elephant) are subject to the common law concept of 'res nullius'. Simply put, res nullius literally means 'property of no one' - but it can be owned by a person, on his or her own accord, by taking possession. This is opposed to 'res communis' (common property that cannot be privately owned) and 'res publica' which is commonly held (public) property, which may be privately owned when such ownership is granted by a relevant state authority. In the case of game, possession (and hence ownership) is commonly achieved, inter alia, through hunting, shooting, seizing, capturing and uniquely marking (e.g. branding) an animal. Under these circumstances, the animal or animals possessed in this manner would be clearly distinguishable from other free-ranging individuals of the same species. The loss of physical control over an animal - for instance, when an unmarked animal is stolen or escapes - would however result in concomitant loss in ownership of that animal (Couzens \& Lewis 2013; Muir 2016).

In seeking to establish an extensive or semi-extensive wildlife area, it is both illogical and impractical for a landowner to take physical control of each of his or her animals in accordance with the common law principle of ownership. It was for this reason that the South African legislature promulgated the Game Theft Act in 1991 (Couzens \& Lewis 2013; Muir 2016; Rumsey 2009). This Act grants ownership of game to that person (or persons) who keeps or holds game on land that is sufficiently enclosed (Section 2). The Act further enables the owner to retain ownership of the sufficiently enclosed game should it escape, or be hunted or seized without, inter alia, the owner's permission (Muir 2016). Thus, the owner of a sufficiently enclosed property (game farm, protected area or private or communal land) would not lose ownership of, or responsibility for, his or her escaped elephant. The corollary of this is that game moving onto a property that is not sufficiently enclosed would not ordinarily become the property of the owner of the land unless this owner takes physical possession of the animals by way of shooting, capture or enclosing them by way of an adequate fence in accordance with the provisions of the Game Theft Act. It would also be counter to natural law for any person to take possession and claim ownership of an animal when it is common knowledge that the animal had recently escaped and was legally possessed by its owner. For instance, should a landowner be the sole source of elephant, and if it would be unlikely that an escaped elephant could have originated from elsewhere, the escaped elephant would be considered property of and hence would remain in the ownership of the landowner. Under such circumstances, the owner of the escaped elephant would need to be given a reasonable opportunity to recover it, as was afforded to SanParks with the escape of 'Sylvester' the lion from Karoo National Park (news24 2016). While this circumstance holds for recently escaped animals, the retention of ownership may not hold where it may be argued that uncommon or uniquely held wildlife have increased in numbers, causing them to reassume their wild (ferae naturae) or non-captive status such that they can move or escape into neighbouring properties (Muir 2016). In such circumstance, these animals would be considered res nullius and hence predisposed to being captured and owned by another person (Magudu Game Company v Mathenjwa 2008).

Taking an international law perspective, notwithstanding that the res nullius principle applies to all including the state, under domestic law game (including elephant) occurring within the country are considered subject to South African sovereignty under public international law (De Klemm 1989). Should elephant, however, move from South Africa to a neighbouring country, those animals would become subject to the sovereignty of the neighbouring state - unless an international agreement determines otherwise (De Klemm 1989). Such circumstance would prevail regardless of whether the landowner was deemed to have been granted a certificate of adequate enclosure in terms of the Game Theft Act, in that domestic legislation does not as such affect the rights and duties of states under public international law. The multilateral environmental agreements pertaining to wildlife - in particular the Protocol on Wildlife Conservation and Law Enforcement and the Convention on Migratory Species - recognise the vested interests abutting countries have in the responsible treatment by their neighbours of wildlife populations that straddle or commute across international borders, and hence stress the need for cooperation and joint management of these populations by the affected countries (Carr \& Scott 1999; Selier et al. 2016). The SADC Protocol sets out a joint requirement for states parties to 'cooperate to develop as far as possible common approaches to the conservation and sustainable use of wildlife' (Article 3). Furthermore, each party shall 'cooperate with other Member States to manage shared wildlife resources' (Article 3). 
The reference to cooperation concerning 'shared wildlife resources' in the SADC Protocol raises the issue of the 'shared natural resources' concept under general international law. As Birnie, Boyle and Redgwell (2009) describe it, the essence of this concept is a limited form of community interest, usually involving a small group of states in geographical contiguity, which exercise shared rights over the resources in question'. The 1974 Charter of Economic Rights and Duties of States, for instance, sets out the following principle:

In the exploitation of natural resources shared by two or more countries each state must co-operate on the basis of a system of information and prior consultation in order to achieve optimum use of such resources without causing damage to the legitimate interests of others (Article 3).

The notion was developed further in the 1978 UNEP Principles on Conservation and Harmonious Utilization of Natural Resources Shared by Two or More States, which received a measure of endorsement by the UN General Assembly (UNGA Resolution 34/186, 1979). According to the UNEP Principles, the main obligations of states concerning shared natural resources concern transboundary cooperation and equitable utilisation (Principle 1). While it is relatively uncontentious that shared watercourses classify as 'shared natural resources' in the above sense, there is some debate about whether migratory and other transboundary wildlife species can be similarly classified (Birnie et al. 2009; Selier et al. 2016). In summary then, customary international law does not appear to impose significant limitations on the sovereignty of South Africa over elephant living on its territory - other than a general requirement to cooperate with neighbouring states regarding the conservation and management of elephant belonging to transboundary populations (Birnie et al. 2009; Bowman, Davies \& Redgwell 2010; Selier et al. 2016).

One suitable way of giving effect to the general duty of cooperation concerning shared natural resources is the joint development and management of transfrontier conservation areas (TFCAs) (Lubbe 2014). For instance, the 2002 Treaty for the Establishment of the Great Limpopo Transfrontier Park records the aspiration of the states of Mozambique, South Africa and Zimbabwe to develop a 'wildlife sanctuary across political boundaries, where animals may freely roam and flourish in keeping with natural ecological processes' (Preamble). To that end, the Treaty establishes several more detailed cooperation commitments and the necessary institutional framework. Similarly, the 2011 Treaty on the Establishment of the Kavango Zambezi Transfrontier Conservation Area (KAZA TFCA) was concluded by Angola, Botswana, Namibia, Zambia and Zimbabwe for the 'primary purpose of harmonizing policies, strategies and practices for managing shared natural resources that straddle the international borders' of the five parties (Article 2, emphasis added).

Another suitable way of applying the 'shared natural resources' concept is the creation of international agreements or plans tailored to particular transboundary wildlife populations (Selier et al. 2016; Trouwborst 2015). A pertinent example is the Collaborative Policy and Planning Framework for the Management of Elephants that was developed by the Trilateral Technical Committee of the Greater Mapungubwe TFCA - and targeting the elephant population of the Central Limpopo River Valley shared between Botswana, South Africa and Zimbabwe (GMTFCA \& TTC 2011; see also Selier et al. 2016).

Unfortunately, however, this need for transboundary coordination is poorly reflected in the South African norms and standards (DEAT 2008). As Selier et al. (2016) note, 'a drawback of the Elephant Norms and Standards is that they do not effectively cater to elephant movements between South Africa and neighbouring countries'. Furthermore, '[g]iven the emphasis on elephant management within fenced areas, the Norms and Standards' implications for the elephant population utilizing the GMTFCA are less than clear' (Selier et al. 2016).

Underpinning the country's sovereignty, section 3 of the NEMBA reaffirms the state as the trustee of the country's biodiversity, and, as such, it has a fiduciary duty to manage, conserve and sustain South Africa's biodiversity in fulfilment of the environmental right in the Constitution's Bill of Rights (Blackmore 2015). As with common law pertaining to trusts in general, although non-possessed freeroaming elephant in South Africa is sovereign to the country, such status should not be misconstrued as ownership. As the trustee, the government cannot arbitrarily become the owner of the objects of the trust, in that the trust objects are held, not owned, on behalf of the beneficiaries. For the government to legally possess free-roaming elephant, it would need to comply with the common law pertaining to the ownership of wildlife, and therein take physical control of the animals. The practical and legal challenges of such an action are vast, discussion of which falls outside the scope of this article.

\section{Elephant management plans}

The provision of norms and standards for use and management of elephant is rooted in section 146 of the Constitution of the Republic of South Africa (1996), where there is, inter alia, a requirement to regulate a matter uniformly across the country. This uniformity was given effect by way of norms and standards to the 2007 Threatened or Protected Species Regulations (TOPS) to the NEMBA.

The objectives of the norms and standards for use and management of elephant include the need to achieve 'specific management objectives of protected areas, registered game farms, private or communal land' which relate to, among other objectives, ensuring the 'long term survival of elephants within the ecosystem in which they occur or may occur in future' (DEAT 2008). The purpose and application of these norms and standards (Section 2) is, therefore, limited to those parcels of land in which the conservation of wildlife is likely to be the primary consideration. Thus, in circumstances 
where the presence of elephant is extraneous to the primary use of the land, and the landowner has not made any purposeful efforts to take possession of the animals, the landowner would not be required to compile and have adopted a management plan.

The norms and standards define the scope in which management plans may apply, by defining the circumstances under which elephant may be kept (Sections 5 \& 6). These include an extensive wildlife system that forms part of a declared protected area or registered game farm, or private or communal land. The keeping of elephant is not defined in the norms and standards, and hence the common use of the term would prevail. As such, the keeping of elephant would imply 'ownership' (Fowler, Fowler \& Crystal 2011). In this case, given that the common law regarding ownership of game would apply, the landowner would need to have at least applied the provisions of the Game Theft Act to take ownership of the elephant that happened to occur on his or her property. In the absence of the landowner taking purposeful ownership of the elephant on his or her property, therefore, the norms and standards would not apply. Further and interestingly, section 5 of the Act is silent on state land that is not a protected area or considered communal land. Organs of state that have land vested in their care, such as the South African Defence Force, would thus not be required to comply with the norms and standards should elephant occur on their vested property.

Notably, in certain cases, free-roaming elephant may still be covered to some degree by an elephant management plan, particularly when the elephant originates from a (protected) area where a management plan applies. For instance, the Elephant Management Plan for the Kruger National Park contains detailed provisions on how to deal with damagecausing elephants outside the National Park, based on an agreement between SANParks and the Mpumalanga and Limpopo provincial authorities (SANParks Scientific Services \& Kruger Park Management 2012).

While the definition of an 'extensive wildlife system' in the TOPS Regulations may encompass land used for purposes other than wildlife conservation, it would be unlawful in the absence of reasonable compensation, for the reasons given above, to compel the landowner or landowners to comply with the norms and standards. Given the sovereignty status of game, the state is ultimately responsible for the country's wildlife. Thus, game considered to be res nullius is ultimately in the trusteeship of the state until such time it is possessed and taken ownership of by a person. Should it be a prerequisite to have management plans in place for all elephant in the country, it would be common cause that the state would have to assume responsibility for free-roaming, unowned elephant.

\section{Conclusion}

The National Norms and Standards for the Management of Elephants in South Africa were brought into force to ensure that, inter alia, wild elephant was subject to a management plan. While these norms and standards clearly apply to proclaimed protected areas, registered game farms and private and communal land that has been sufficiently fenced in accordance with the Game Theft Act, the same cannot be said for open, functionally unfenced land on which elephant naturally occurs. A lacuna does appear to exist in the norms and standards where elephant are free-roaming and where a person has not taken possession of the animal. Furthermore, a lacuna in the norms and standards is evident where ownership of elephant is ambiguous or where the land is in the ownership of a state and is vested for purposes other than wildlife management. Given that, in terms of the provisions within the Constitution, norms and standards are to bring uniformity to elephant management across the country, the 2008 National Norms and Standards for the Management of Elephants will need to be amended to accommodate this lacunae.

\section{Acknowledgements}

The authors would like to thank Ms Magdel Boshoff, Deputy Director, Threatened or Protected Species Policy Development, Department of Environment, Pretoria, for raising the uncertainty regarding who is responsible for management plans for free-roaming elephant. The legal instruments cited and discussed in this article are current as of 14 April 2017. The ideas, arguments and opinions expressed in this article are the authors' own and do not necessarily represent those of Ezemvelo KZN Wildlife, the University of KwaZulu-Natal or Tilburg University.

\section{Competing interests}

The authors declare that they have no conflicts of interest in writing this article.

\section{Authors' contributions}

The entire article was drafted and finalised by the authors. A.B. drafted most of the article and undertook the founding research. A.T. contributed most of the research on the transboundary context.

\section{References}

Birnie, P., Boyle, A. \& Redgwell, C., 2009, International law and the environment, 3rd edn., Oxford University Press, Oxford.

Blackmore, A., 2015, 'The relationship between the NEMA and the public trust doctrine: The importance of the NEMA principles in safeguarding South Africa's biodiversity', South African Journal of Environmental Law and Policy 20(2), 89-118.

Blackmore, A., 2017, 'Public trust doctrine, research and responsible wildlife management in South Africa', Bothalia 47(1), a2217. https://doi.org/10.4102/abc. v47i1.2217

Bowman, M., Davies, P. \& Redgwell, C., 2010, Lyster's international wildlife law, 2nd edn., Cambridge University Press, Cambridge.

Carr, C.L. \& Scott, G.L., 1999, 'Multilateral treaties and the environment: A case study in the formation of customary international law', Denver Journal of International Law and Policy 27(2), 313-336.

Constitution of the Republic of South Africa, Act 108 of 1996.

'Convention for the Preservation of Wild Animals, Birds, and Fish in Africa', 1900, British Parliamentary Papers 101(56), 825-837.

Convention on the conservation of migratory species, Bonn, Germany, of 23 June 1979, in force 01 November 1983, United Nations Environmental Program, viewed 23 April 2018, from https://www.cms.int 
Couzens, E. \& Blackmore, A., 2010, 'A millennium overturned: The long history in England and South Africa of laws against hunting with dogs, and recent statutory changes in
the province of KwaZulu-Natal', in M. Kidd \& S. Hoctor (eds.), Stella luris: Celebrating 100 years of teaching law in Pietermaritzburg, pp. 298-321, Juta, Pietermaritzburg.

Couzens, E. \& Lewis, M., 2013, International encyclopaedia of law: Environmental law - South Africa, Kluwer Law International, Alphen aan den Rijn.

De Klemm, C., 1989, 'Migratory species in international law', Natural Resources Journal 29(4), 935-978.

Department of Environmental Affairs and Tourism (DEAT), 2007, Threatened or Protected Species Regulations (TOPS), National Environmental Management: Biodiversity Act (10/2004): Threatened or Protected Species Regulations, DEAT, Pretoria.

Department of Environmental Affairs and Tourism (DEAT), 2008, National Environmental Management: Biodiversity Act, 2004 (Act 10 of 2004): National Norms and Standards for the Management of Elephants in South Africa, Department of Environment Affairs \& Tourism, Pretoria, South Africa.

Fowler, H.W., Fowler, F.G. \& Crystal, D., 2011, The concise Oxford dictionary: The classic first edition, Oxford University Press, Oxford.

Greater Mapungubwe Transfrontier. Conservation Area (GMTFCA) \& Trilateral Technical Committee (TTC), 2011, Collaborative policy and planning framework for the management of elephants in the greater Mapungubwe Transfrontie Conservation area, 2011-2020, Peach Parks Foundation, Stellenbosch.

Hopkinson, L., Van Staden, M. \& Ridl, J., 2008, 'National and international law', in K. Mennell \& R. Scholes (eds.), Elephant management: A scientific assessment of South Africa, pp. 477-536, Wits University Press, Johannesburg.

Lubbe, W.D., 2014, 'A legal appraisal of the SADC normative framework related to biodiversity conservation in transfrontier conservation areas', in L.J. Kotzé \& T. Marauhn (eds.), Transboundary governance of biodiversity, pp. 204-232, Martinus Nijhoff Publishers, Leiden.

Mackenzie, J.M., 1988, The empire of nature: Hunting: Conservation and British imperialism, Manchester University Press, Manchester.

Magudu Game Company (Pty) Ltd v Mathenjwa NO and Others 20082 All SA 338 (N).
Muir, A., 2016, 'Offences, game and property - Some unresolved issues of ownership of wild animals in South Africa', Stellenbosch Law Review 27(1), 136-160.

National Environmental Management Biodiversity Act 10 of 2004.

news24, 2016, 'Karoo lion caught after latest escape', viewed 14 April 2017, from http://www.news24.com/Green/News/karoo-lion-caught-after-latestescape-20160331

Organization of African Unity, 1968, African convention on the conservation of nature and natural resources, Doc. No. CAB/LEG/24.1, Organization of African Unity, Algiers.

Republic of South Africa, 1991, Game Theft Act 105 of 1991. Government Gazette, Vol 313, No. 13352.

Rabie, M.A., 1976, South African environmental legislation, University of South Africa, Institute of Foreign and Comparative Law, Pretoria.

Rumsey, A.B., 2009, 'Terrestrial wild animals', in H.A. Strydom \& N.D. King (eds.), Fuggle \& Rabie's environmental management in South Africa, 2nd edn., pp. 394-424, Juta, Lew.

SADC, 1999, Protocol on wildlife conservation and law enforcement, Southern African Development Community.

SANParks Scientific Services \& Kruger Park Management, 2012, Elephant management plan for the Kruger National Park, 2013-2022, SANParks Scientific Services \& Kruger Park Management, Pretoria.

Selier, S.A.J., Slotow, R., Blackmore, A. \& Trouwborst, A., 2016, 'The legal challenges of transboundary wildlife management at the population level: The case of a trilateral elephant population in Southern Africa', Journal of International Wildlife Law \& Policy 19(2), 101-135. https://doi.org/10.1080/13880292.2016.1167460

Tennant, H. \& Jackson, E.M. (eds.), 1895, 'Statutes of the Cape of Good Hope' 16521895 (II) 1872-1886. Juta, Cape Town.

Trouwborst, A., 2015, 'Global large carnivore conservation and international law', Biodiversity and Conservation 24(7), 1567-1588. https://doi.org/10.1007/ s10531-015-0894-8 